\title{
AUGuSTINE, HIS SERMONS, AND THEIR SIGNIFICANCE
}

Author:

Johannes van Oort ${ }^{1,2}$

\section{Affiliations:}

${ }^{1}$ Radboud University,

The Netherlands

${ }^{2}$ Department Church History and Church

Polity, University of

Pretoria, South Africa

\section{Correspondence to:}

Johannes Van Oort

e-mail:

j.van.oort@planet.nl

\section{Postal address:}

Van Renesselaan 24 , 3703 AH ZEIST, The Netherlands

\section{Keywords:}

Augustine; psalms; sermons; congregational worship; Augustine's preaching techniques

\section{Dates:}

Submitted: 05 Jan. 2009 Accepted: 10 June 2009 Published: 05 Oct. 2009

How to cite this article: Van Oort, J., 2009, 'Augustine, his sermons, and their significance', HTS Teologiese Studies/ Theological Studies 65(1), Art. \#300, 10 pages. DOI: 10.4102/htsv65i1.300

This article is available at: http://www.hts.org.za

(c) 2009. The Authors. Licensee: OpenJournals Publishing. This work is licensed under the Creative Commons Attribution License

\section{ABSTRACT}

Augustine's sermons provide a unique source in explaining his influence from the 5th century onwards as a theologian and pastor, a minister of the Word preached and celebrated in the sacrament. Of particular value in this regard are his sermons on the Psalms. Issues of authenticity are also considered in this article. The influence of Augustine's sermons was widespread through their tradition and adaptation by others. A substantial and reliable corpus of his sermons is available today. As a pastor, Augustine was anxious to challenge heresy in his preaching, especially to confront the Donatists, Manichaeans and Pelagians. His preaching is considered in the wider context of congregational worship with its origins in the synagogue. Of special importance are his preaching techniques, while his doctrine of 'the inner teacher' (magister interior) is equally significant. Essential elements of Augustine's theory and practice became influential in the early days of the Protestant Reformation (Luther, Calvin and others). The author briefly touches on the question of their relevance for today's congregational worship.

\section{INTRODUCTION}

Augustine is a father of the Christian Church of Africa and his worldwide influence is unparalleled even today. Sixteen centuries separate him from us, but throughout that long period his presence has been felt continually. He has been a contemporary of nearly every generation (Backus 1997; Marrou 1955:147-180)

Surprisingly, this has been possible particularly because of his sermons. ${ }^{1}$ When the man who had been searching for God's treasure for thirty years eventually discovered the treasure, he worked with it for forty years. A genius became a humble servant in the Church of Christ. He who had sought philosophical speculation became a practical pastor. The long-time desperate wanderer became a guide for centuries.

We might expect that Augustine's importance for later centuries would lie primarily in his well-known major writings. First of all, in his monumental City of God, the 22 books that narrate history from creation to eschaton in the metaphor of the two cities, Jerusalem and Babylon (Van Oort 1991). Moreover, in his Confessions - a document both highly literary and spiritual - he recounts his own peregrination and final homecoming (Kotzé 2004). This is expounded on in his majestic dogmatic work, The Trinity (Kany 2007).

However, the above is only partially true. No one will deny that the work in which Augustine develops a theology of history has determined in more than one respect the vision of many a Christian philosopher, theologian or politician during the course of the centuries. Nor that the Confessions have been read throughout the ages, and certainly with great appreciation in modern times. Furthermore, most will agree that, in addition to The Trinity, his dogmatic works - particularly the numerous writings directed against the Pelagians - have had a decisive impact. It was mainly because of these anti-Pelagian writings (Van Geest \& Van Oort 2005) that the honorary title of doctor gratiae was bestowed on the church father and that reformers such as Luther and Calvin so often referred to him (Luther 1889:18, 640; Smits 1956:271; Lange van Ravensway 1990; Van Geest \& Van Oort 2005; Van Oort 1992:92-103). And they are not alone. ${ }^{2}$

But there is more. In the brief outline of his mentor's work which he wrote shortly after Augustine's death, Possidius portrayed him above all as a pastor (Elm 2003:140-143; Possidius 1975:127-241). This was the principal aspect of the life of the bishop of Hippo: the day-to-day ministering to his people, in the first place to the members of the Christian congregation in a harbour city somewhere in the Western part of the vast Roman Empire.

In a striking way one can see this in his œuvre. In all of Augustine's writings, in the well-known major works, in the many letters, in the various other writings, he wanted to be a verbi divini minister, a servant of the word of God as he heard it in the Bible. And the ministry of the Word meant to him the celebration of the Eucharist (a matter to which we shall return). An especially important part of his being a minister

1. His most voluminous book became his collected explanations of the Psalms, the so-called Enarrationes in Psalmos. The majority of these explanations have been preached in church. Apart from these sermons, we have several other collections. All in all, many hundreds ef of sermons have been preserved, either completely or in fragments. In March 2008 the discovery of some new sermons of Augustine, found in a codex in Erurt (Germany), was made public. (See for instance the very first news report, based on the present writer's notes, in the Dutch newspaper Trouw (www.trouw.nl). The official publication of these sermons is scheduled for 2008 and 2009 in the specialist journal Wiener Studien.

2.In the religious controversies in Europe, in particular during the 16th and 17th centuries, it was the Roman Catholics who especially appealed to Augustine (Grane, Schindler \& Wriedt 1993, 1998; Polman 1932; Stakemeier 1937;). As a rule, however, there is an essential difference between the approach of the Roman Catholics and the Protestants. While most of the Roman Catholics quoted from all of Augustine's works indiscriminately, the Reformers and their direct successors followed another lead. In the footsteps of the humanist Erasmus (whose critical edition of Augustine's Opera Omnia was published by Froben in Basle in 1528-1529), they evaluated Aunt Augustine's works according to the dfferent phases of his ife. In other words, they read Augustine in retrospect, that is from the perspective of the many pseudo-Augustinian writings (Van Oort 1997a:661-700, 1997b:67-81, 1989:181-190, 1991:55-70). 
was his preaching. Thus, strikingly, his most extensive body of work is not De Trinitate, not even the 22 books De civitate Dei, but his collected sermons on the Psalms. ${ }^{3}$ It was particularly through his sermons that the church father exerted an immense influence on later generations. Augustine's preaching talent is his most lasting gift.

\section{TRADITION}

For nearly 40 years - starting in 391 when he became a presbyter at Hippo Regius - Augustine used this special talent. Almost from the beginning his sermons were recorded by private stenographers and passed around. Possidius reported: 'Everyone employed stenographers, as much as he wanted and was able to, so that what Augustine said was retained in written form' (Possidius 1975:7).

Remarks like the above indicate that there were stenographers in the churches where Augustine preached, and that they must have been present frequently. They recorded what they heard, either for themselves or commissioned by others. During Augustine's lifetime, collections of his sermons had already begun to appear based on the transcripts of these notarii.

This fact presents us with various problems. First of all, are these accounts accurate representations of the sermons? A stenographer's report is not the same as a tape or a video, even though the art of stenography had attained a very high level at that time (Hagendahl 1974:24-38). Secondly, and above all: How can we be absolutely certain that what has come down to us is the work of Augustine himself?

For a long time this last question in particular has been the subject of much investigation, and rightly so. From the time they were first delivered, Augustine's sermons, sometimes separately but more often in collections, set off on a path through history. Not only were they read for personal edification or read aloud in church for the improvement of the congregation - the 'reading service' appears to be as old as the Christian Church and was known even earlier in the synagogue (Zunz [1892] 1966:357-358) - but they were also consulted by later preachers. They were already being quoted by his contemporaries (Pontet 1945:8, 28; Mohrmann 1948) and their circulation increased particularly when the Vandals were ravaging Africa and many people fled to Gaul, Spain or Italy. Augustine's pupil Quodvultdeus, for one, admired his teacher so much that he adopted his manner of preaching. His sermons circulated under Augustine's name, especially in Italy. Most importantly, a hundred years later Caesarius, bishop of Arles in the south of Gaul and filled with a great missionary fervour, would re-edit entire collections of Augustine's sermons. These sermons, slightly adapted and often only through a new beginning or end, were read aloud in the Gallic churches. Later preachers in turn used these editions. For example, when the famous Boniface preached the Gospel to the Frisian and German tribes, 'his' sermons contained many Augustinian ideas, mostly through Caesarius, sometimes even taken directly from Augustine (Millermann 1933:23-24).

Thus very early on, the influence of Augustine's sermons spread as far as the northern parts of Europe. But after all those transplantations and adaptations, how was it possible to distinguish what originated with Augustine from what was added later? Great appreciation should be expressed for Erasmus' scholarly work on the publication of Augustine's sermons (Basel 1529 , an edition which Calvin, among others, used extensively) (Smits 1956:201-205). Erasmus' work was considerably amended later by the so-called Louvain scholars in their edition published by Plantijn between 1576 and 1577. Later on, important research was carried out by the Benedictines of the congregation of St.

3.This can easily be seen by looking at any Latin edition, such as the one edited by J-P. Migne in dense Latin columns (which may be counted as pages) in his Patrologia Latina: De Trinitate ca. 280 pp. (in MPL 42); De civitate Dei ca. 800 pp. (in MPL 41), Latina: De Trinitate ca. $280 \mathrm{pp}$. (in MPL 42); De civitate Dei ca. $800 \mathrm{pp}$. (in MPL 41),
but also in the Enarrationes in Psalmos in two separate volumes of altogether 1900 but also in the Enarra
pp. (MPL 36-37).
Maurus in preparation for their collection of Augustine's sermons that appeared in 1683. In the previous century excellent additions to their investigations had been made, particularly by Germain Morin and André Wilmart, likewise members of the Benedictine order. In the past and more recently, researchers such as Cyrille Lambot, P.-P. Verbraken and François Dolbeau continued their work, to mention but a few (Dolbeau 2005; Madec 1998:395-411; Rebillard 1999:773-392). ${ }^{4}$ On the basis of a number of internal and external criteria - i.e., language, style, content in comparison with that of other writings and quotations from the Bible - it is possible to make subtle distinctions between the genuine and the spurious. And although there is still disagreement today concerning details (Dekkers \& Gaar 1995:110-124; Mandouze 1968:599-615; Verbraken 1976; Zwinggi 1970:93-94), it can be stated that we now increasingly have a very reliable picture of Augustine's sermons in terms of number, length and content. Nearly 900 sermons - either complete or partial - known to be by Augustine, have come down to us.

Notwithstanding this abundance of material, our knowledge of Augustine as a preacher remains incomplete. Stenographers took down his words, but they often summarised them. The timbre of his voice, his facial expressions, his gestures, in short what was referred to in ancient times as the actio, are lost forever. Only a shadow remains of that presence. Possidius said that Augustine had to be heard (Possidius 1975).

\section{THE DELIVERY OF THE SERMONS}

Nevertheless, enough has been preserved from Augustine's own work and the works of others to give us an almost complete picture of him as a preacher. The most important location for delivering his sermons was Hippo in Roman Africa, at that time a seaport town of about 30000 inhabitants, with its vast hinterland/countryside. He usually preached in the basilica maior, also called the basilica pacis. When he was not elsewhere - he travelled frequently, especially to Carthage where he attended synods or other conferences and preached many times (Perler 1969) - he 'administered God's Word' every Saturday and Sunday. During Lent and festival seasons he preached daily; sometimes giving special catechetical and other sermons as often as six times a day (Poque 1966:80). ${ }^{6}$ Several of these were of short duration, often lasting no more than a few minutes.

However, the majority of his sermons must have lasted about half an hour; many were longer, some of them longer than an hour, even as long as two hours (Olivar 1966:143-184, 166-177; Pontet 1945). However, it was almost impossible for a listener's interest to flag. Augustine held the attention of his listeners, in his home church and elsewhere, time after time. Like Ambrose, he expressed his dissatisfaction with his weak voice more than once and specifically asked for silence. It should be noted that his congregation was made up of enthusiastic inhabitants of Roman Africa who - in several respects resembling so many present-day Africans - were easily moved and expressed their approval noisily. They frequently applauded, signalling that they understood him; and sometimes there were murmurs of disapproval. In a letter to his colleague and old friend Alypius from Thagaste, Augustine wrote that his listeners were moved to tears and that he, too, was deeply affected (Eph 29, 7).

It is mainly from this letter, and from various remarks in the sermons and a passage in the City of God (De Civitate Dei 22, 8), that we are able to reconstruct the worship service in Augustine's time. We will primarily confine this description to its first part, 4.In May 2008 a congress on Augustine's sermons ('Ministerium sermonis. An International Colloquium on Saint Augustine's Sermones ad populum') took place in Turnhout and Leuven in Belgium, the acts of which are scheduled to appear in 2009.

5.Many of these sermons delivered in Carthage have been preserved. Sermons given at Thagaste, Bulla Regia, Utica and, for instance, distant Caesarea Mauretaniae have also come down to us.

6.She also relates that, as a consequence, Augustine once said on an Easter morning that he could not preach anymore. 
the Service of the Word (Hamman 1986:221-244; Roetzer 1930; Van der Meer 1947:342-350; Zwinggi 1970:95-113).

After the procession into the church building, the minister used, as his call to worship, the well-known words, Dominus vobiscum: 'The Lord be with you.' The congregation responded: 'And with your spirit.' Then the minister prayed that the Lord's peace be with the lector. The lector was standing ready to read the Scriptural lessons

It would seem that Augustine chose these readings himself, taking into consideration the well-known church festivals, when appropriate and expected. In doing so he followed an existing tradition. Thus on Good Friday it was customary to read the account of the Passion as it occurs in the Gospel according to Matthew. On one occasion, when Augustine wanted to vary this, there was much consternation among his flock. On Ascension Day and at Whitsun the appropriate texts were taken from the Gospels or the Acts of the Apostles. Apart from that, there was the continuous reading and subsequent explanation of biblical passages that followed each other, for example from the Book of Psalms, the Gospel according to John or the First Letter of John. Originally, however, only certain sermons (that had come down to us as part of a complete series) were preached in succession. Often, after a hiatus of a number of months or even years, the series was resumed. Furthermore, part of the series was not delivered during Church service, but dictated separately. ${ }^{7}$ They were often meant to be used by others in their preaching, and were in the form of detailed outlines of sermons. Augustine realised that '... there are people who are good speakers but are unable to compose a sermon. If they use ideas of others that are written intelligently and in a good style, memorise them and deliver them to the people, they are doing nothing objectionable. In this way do many persons - and that is a very beneficial experience - learn to be preachers of the truth. ${ }^{\prime}$

Hippo's bishop had a reason for wanting to choose the readings himself. The minister is, after all, a divinarum scripturarum tractator et doctor, 'an interpreter and teacher of the holy Scriptures'; he must 'as defender of the true faith and adversary of heresy, teach others to embrace good and throw off evil.' ${ }^{\prime 9}$ This is apparent in his choice of Scriptural readings and the explanations that followed. As a rule, they dealt with the concrete situation of the congregation. When Augustine preached a series of sermons, for example sermones 153 to 156 on $\mathrm{Rm} 7$ and 8, or gave his tractates on the Gospel of John and 1 John, he connected his message directly with the situation of his hearers: the former would refer repeatedly to the doctrines of the Pelagians, while the latter would often deal explicitly with the Donatists.

For a long time - for instance in the period when reformers such as Bucer and Calvin were active in reforming the worship service - there was an almost universal (yet incorrect) assumption that in patristic times the preachers in their sermons dealt with the biblical texts in a consecutive order. And it was none other than Augustine's sermons that were supposed to provide the evidence for this. However, the opposite is closer to the truth: less than one tenth of the sermons actually delivered by Augustine deal with consecutively-read Bible texts (Zwinggi 1970:85-129). As for John Chrysostom - another famous preacher who serves as role model for many Protestant reformers - there is also no proof that he followed a strict lectio continua of the Bible in his sermons. Many of the sermons of his extensive and influential series of homilies were most probably dictated, and not actually preached (Zwinggi 1970:87).

It is worth noting that - as far as we can discern - in the divine service in Augustine's Hippo, or elsewhere, three passages

7.This was almost certainly the case with a number of Enarrationes in Psalmos (for instance the 32 in Ps $118=$ Hebrew 119) and with the last 70 tractates (55-124) on the Gospel according to John (La Bonnardière 1965:122-126, 141).

8.De doctrina christiana $4,29,62$

9.De doctr. chr. 4, 4, 6: 'Debet igitur divinarum scripturarum tractator et doctor, defensor rectae fidei ac debellator erroris, et bona docere et mala dedocere. from the Bible were recited during the Scriptural lessons: First a passage from the Old Testament or one from the New Testament outside the Gospels, then a psalm, and finally the Gospel reading. This last lesson formed the climax, for here Christ is speaking: 'The mouth of Christ is the Gospel' (Sermo 85, 1 - see also sermo 302, 1 or Tract. in Ioh. Ev. 30, 1).

It is striking that there was always a psalm reading. A parallel with the early synagogical order of worship may be drawn here, i.e., the Torah reading was followed each time by a psalm. This practice was later dropped in the synagogue because Christians were using the psalms and gave them a Messianic interpretation in relation to Jesus Christ. However, the custom of including a reading from the Psalms continued in the Christian church.

Once we realise this, we can appreciate fully the important place given by Augustine and others (e.g. Hilary of Poitiers, Ambrose and Chrystostom) to the Psalms in their sermons. Nearly half of Augustine's sermons that have come down to us consist of Christological interpretations and applications of psalm texts. Many of these sermons were delivered in services other than the main worship service. Here, too, the lector included a psalm as one of the Scriptural readings.

The way in which the psalm was presented differed from the reading of the other Bible passages. The lector-cantor sang the psalm and the congregation sang its refrain in response. This is evident in many sermons: 'We have heard and have sung' ... From the whole congregation resounded the refrain, as its first response to the Word of God. ${ }^{10}$ Hence it is very likely that Augustine's preference was for responsorial singing over antiphonal singing.

The latter type, new then to the church in North Africa, was also used. It involved a division of the congregation into two choirs. But it is not clear in what form, or how frequently, the rest of the singing during the worship service occurred. Augustine was familiar with Ambrose's well-known hymns, as we can see from a number of references he made to them (Conf. 9, 12, 32; Retract. $1,21(20), 1)$, and he had his congregation sing them. But the man who for many years had moved in Manichaean circles and had experienced the seduction of their heretical hymns (Conf. 3, 7, 14; En. in Ps. 140, 11; C. Faust. 13, 18; De mor. II, 55), had very exacting demands with respect to hymns other than the psalms: 'Hymns are laudations of God set to music. Hymns are songs containing the praises of God. If there is praise, but it is not the praise of God, it is not a hymn' (En. in PS. 72:1). Once when he was preaching in the North African city of Utica on Psalm 145, a psalm of praise, he observed that the best place to look for the praise of God was in the Scriptures - in the Psalms themselves, 'lest we stray from the way, be it to the left or to the right. Yes, beloved, I venture to say to you: so that God should be praised by man in an appropriate way, God praised himself' (En. in PS. 114, 1. See esp. En. in Ps. 34, s.1:1).

After the readings, including the sung Psalm with its congregational response, the bishop took his seat: he preached sitting down. The listeners usually stood. The men - not only as in ancient society, but once again as in the ancient synagogue apart from the women.

The congregation was generally addressed as 'beloved,' 'brethren,' or 'beloved brethren' (Krause 1968:175-188). Even though non-Christians were often present, and certainly people who had not yet joined the ranks of the baptised, everything points to the fact that Augustine was addressing the congregation 'of the Lord'. It was not in a casual crowd, but in the midst of the congregation of Christ that the preaching of the Word occurred: in their midst 'the banquet of the holy Scriptures' (sermo 90:9) was served.

10.We notice a liturgical order that is still in use and that is apparently well founded: the scriptural readings, alternating with or followed by psalm singing in response to the reading. This formula of singing of the text by the lector-cantor with a to the reading. This formula of singing of the text by the lector-cantor with a
congregational response occurred elsewhere, too, in the early Christian church, a formula that seems to have its origin in the synagogue. 
The introduction to the sermon was quiet and simple. More than once the manuscripts indicate that Augustine offered a short prayer in which he asked God for enlightenment and help:

And He to whom we have said: You held my right hand and you guided me by your counsel and afterwards will receive me with glory [PS 73:23-24], may He raise our hearts to clearer insight, and may His mercy and grace aid me in speaking and you in making judgements.

(sermo 23,1 - see for instance sermo 153,1; 169,1;

En. in Ps. 91,1; Tract. in Ion. Ev. 74,1)

Here, too, we find an essential element of Augustine's preaching in its practice: Preaching is the ministering of the Word, and the guidance of the Holy Spirit in speaking and listening is indispensable to it. That is why, at the beginning as well as later on in the sermon, he asks his listeners to pray for him (Ep 29:7: '... imperata oratione ...'). As with other preachers of the Early Church, there is an emphasis on the minister's praying and the congregation's prayerfully listening (Nibergall 1955; Olivar 1972:429-443). After all, preaching is not deemed to be the work of humans, but the ministry of the Spirit: 'there is a fire blazing in the Word of God, it is the glow of the Holy Spirit; if the minister does not glow as he preaches, he cannot fire up the one to whom he is preaching' (Sermo 22, 7 and En. in Ps. 103, s. 2, 4, 5 resp).

The Paraclete is the real exegete, and for the Paraclete's presence both the congregation and the minister must pray. In his book on the art of preaching, Augustine states this explicitly for the minister: sit orator antequam dictor, be he first a prayer, then a speaker.

When the moment has come to speak, one should raise, before speaking, one's thirsty soul to God, so that one may be able to dispense to others what one has drunk, to pour out to others what one has drunk in (...). And who else can bring about what should be said by us is said, and is said as it should be, than He in whose hand are we and our sermons?

(De doctr. Chr. 4, 15, 32)

Augustine rarely announced the theme of the sermon at its beginning. He 'simply' explained and analysed a passage usually a number of passages - read from the Scriptures. There was no crystal-clear structure in his sermon. Moreover, the sermon started and ended quite abruptly. It should be realised in this connection that, after a meditative preparation at home, Augustine was in active contact with his listeners as he spoke. In that dialogue with the congregation he poured out his heart profusely. He did not deliver a prepared written speech, or a declamation, much less a logical reasoned argument. However, he presented the Word in a lively manner, displayed its treasures, and laid them out for the congregation to see. Augustine did not go on to the next part of the sermon, or conclude, until his listeners had indicated that they had understood what he was saying and had taken it to heart.

A few other characteristics of this preaching may be mentioned as well. (Language and style will be discussed at greater length presently, as well as his exegesis.) Augustine preached about essentials. He did not withhold anything from ordinary and sometimes very simple people. He explained to them the meaning of the Scriptures, and tried to make this clear with everyday examples. In Christ's school (schola Christi) (sermones $98,3 ; 122,3 ; 177,2)$ there are people of all walks of life. Therefore we find repeatedly in the sermons what Augustine tried to express elsewhere in profound scholarly discussions. Not that he tried to say everything at once - the wine of Cana was served in small glasses (Tract. in Ioh. Ev. 9, esp. 9f). In fact, there was nothing he considered too lofty or too profound for his listeners. Thus he discussed in the course of his preaching of the Word the dangers of schism and heresy, the many intellectual and ethical problems connected with Christian belief as well as the questions of 'our turbulent times'.11

11.See for instance sermo 80 on the fall of Rome, the capital of the mighty Roman Empire.
It is interesting to note how often Augustine quoted texts from the Bible in his sermons. He explained a passage, using mainly other Bible texts as a commentary on the Scriptural readings. In doing so he shed some light on the connection between them. An unusual word, a number or some other detail frequently received abundant attention, and each time he quoted ensuing Bible texts. He did so from memory. Like his colleagues and many of his listeners he knew almost the entire Bible by heart. It might seem to us that he chose his texts more or less at random, or only on the basis of their sound.

One might ask where that manner of biblical interpretation came from. Did it originate with the classical grammatici? Until now it has been attributed to them. The ancient grammarians explained a passage from their Homer or Virgil word for word, verse for verse, giving parallels etc., without clearly placing it in its context. According to this view, the 'holy' text book had been changed, but the method had remained (Brown 1967:37; Marou 1955:469-503; Van der Meer 1947:388).

However, it seems worth considering whether a completely different example might be examined as well, i.e., the Bible exposition and preaching in the synagogue. There, too, the passage was repeated verse by verse, word by word. There, too, some Scriptural passages were explained through paraphrases and comparisons and, most importantly, in the antique synagogue's sermons other passages from Scripture were quoted in order to make the text of the sermon clear. This last method in particular was emphasised and considered a special art. It was likened to stringing (charaz) pearls (Billerbeck 1928:IV, $1,171 \mathrm{ff}, 176)$.

However, this is not the place to fully examine this similarity. In my opinion this could be the fruitful subject of a separate study. It should be noted here that it is not only the method of Scriptural exposition (especially the principle of sacra scriptura sui interpres - 'Scripture explains itself' - including what looks to us like a rather random choice of quoted passages) that shows striking parallels between the preaching in church at the time of Augustine and that in the early synagogue. Notable in both are, among other things, also the fact that there were lectors who were standing when they did their part in the service; that the preacher was seated; that in the congregation the men and women were separated; and that there was a recitation of the Psalms. It is also noteworthy that Augustine preached on Saturday (the Jewish sjabbath) as well as on Sunday. For modern research in which the Jewish origin of Christianity in Africa is increasingly recognised (Danielou 1977; Frend 1961:280-284; Quispel 1982:257-335; Van Oort 1991:365-371) $)^{12}$, there is important information in Augustine's sermons that would appear to provide interesting evidence.

Here we will make a few additional annotations on the rest of the worship service. Following the sermon, announcements were sometimes given concerning important events in the life of the congregation, such as religious festivals to be celebrated. Then, after everyone had turned to face the East, there were prayers. Augustine asked God to protect and guide those who were gathered together in the church. These short prayers were most likely offered especially on behalf of the catechumens (those who were not yet baptised) (Zwinggi 1970:104-112) and the penitents. These people, having received their blessing, then had to leave the church building. The service continued with the celebration of Holy Communion.

The second part of the main worship service needs no further description in this context (Roetzen 1930:113-125; Van der Meer 1947:350-355). The fact that Augustine considered the sacrament of Holy Communion (the Eucharist) a special form of ministry of the Word will be discussed later. As to the usual activities of

12.A recent series of contributions to the Augustinus-Lexikon on Augustine and the Jews in Roman North Africa, were scheduled to appear at the end of 2008. The main one has already been published online (www.augustinus.de). 
the church father in the context of 'the service of the Word', it can be noted, finally, that besides the complete worship services on Sunday and Saturday, ${ }^{13}$ there were many other gatherings, i.e., every day early in the morning and in the evening, and sometimes in the afternoon. Easter and Whitsun vigils were held, as well as vigils prior to days on which apostles and martyrs were also commemorated.

These and other gatherings, which were not usually attended by the entire congregation, can also be characterised as services of the Word. Sometimes there was a sermon, often Holy Communion was celebrated, and there were always readings from the Bible and/or other scriptures (for instance acts of the martyrs), prayers and singing. This is made clear in a sermon on a passage from the Psalms in which Augustine gives his listeners the example of the industry of 'God's ant'. 'She gets up every day, runs to the church of God, prays, listens to the reading, sings a hymn (most likely a psalm, as Augustine often referred to psalms as hymns), repeats what she has heard, meditates on it, and keeps deep down in her soul the grains she has gathered from the threshing-floor' (En. in Ps. 66, 3; En. in Ps. 33, s.2, 14; Tract. in Ioh. Ev. 3, 21). This example brings to mind Monnica, as depicted by her son in the Confessions,

... who did not fail one day to give an offering at Your altar, who came twice a day, early in the morning and in the evening to Your church without ever missing, not to hear idle talk and old wives' tales, but in order that she should hear You in Your words and that You should hear her in her prayer.

(Conf. V, 9, 17)

\section{HOW SHOULD ONE PREACH?}

After this rather detailed description of the practice of Augustine's preaching, we can confine ourselves to a few comments about the theory of preaching. In doing so, we are acting in the spirit of Augustine. Not until he had been preaching for a number of years did Augustine discuss the theory of preaching, and then only briefly. This discussion can be found in the fourth book of De doctrina christiana, which he wrote towards the end of his life. In it he gives instructions for others, but at the same time draws a portrait of himself.

How should one preach? The author of the brief exposition emphasises first that the content of the sermon should be thoroughly biblical. It is necessary to have a detailed knowledge of the Bible before setting out to present one's findings. Auxiliary fields of knowledge are indispensable, i.e., in the first place languages, essential for one's own exegesis and for the correct use of existing Bible translations. Furthermore, a good general understanding is required of mathematics, music, history, geography, botany, geology, astronomy and, among other areas, dialectics and rhetoric (eloquentia). Augustine demonstrates this in Book II. In the third part he mentions the difficulties encountered in Bible interpretation and treats at length and approvingly the exegetical rules as set forth by the Donatist scholar Tyconius. Earlier, in the first book, he discussed the difference between using (uti) and enjoying (frui). How should the Christian deal with knowledge and culture? He can only enjoy God and His kingdom, i.e., he may use the things of this world in so far as they are directed towards this purpose. This is also true of fields of knowledge: they are valuable, but not in themselves. They are merely auxiliary sciences, in the service of the higher ideal.

In later centuries these explanations had an immense influence, most significantly in the European Middle Ages, but also long afterwards. They also formed the foundation for Augustine's subsequent brief manual on the art of preaching.

In what form should the contents of the Bible be presented? It is notable that Augustine opens his exposition in Book IV with some

13.That Holy Communion was also celebrated on Saturday is at least probable (Zwinggi 1970:130). In any case we know there was a sermon then. remarks that for his time and in the light of his own background are nothing less than revolutionary. The former rhetor first asks himself what the attitude of the Christian preacher should be towards the achievements of classical rhetoric. His answer is that these are in themselves neither necessary nor indispensable. All that matters is how they are used - they may be a means, not an end.

In this way fundamental questions were raised regarding an age-old cultural ideal (Marrou 1939:505-545; Mohrmann 1874). ${ }^{14}$ Classical eloquence and the system of rhetorical devices employed to attain this eloquence are not essential. The rules of academic rhetoric are at most useful. The future minister may study them, but they are not a condition for his ministry.

Does Augustine not consider it desirable that the one who is preaching the Word has an eloquent delivery? Of course he does. But for acquiring it he points in an entirely different direction. The Bible itself is, after all, eloquent; it possesses a language whose beauty must be discovered. This African bishop reads the Bible as a book of beauty. If the minister-in-training studies the Scriptures daily, he will master the desired Christian eloquence as a matter of course. He can also master it through reading Christian writers, especially Ambrose and Cyprian, and through listening to good speakers.

These remarks are revolutionary, first of all for their definite reserve with regard to classical rhetoric. Augustine realises that for Christian language and style a danger also lurks, i.e., by lapsing into a cult of the eloquent word. In the context of classical culture it was unheard of to say, as he does, that one could be eloquent without following the ancient rules. However, Augustine dares to point out that natural talent could be developed through the reading of good examples - not the pagan classics, but above all the Bible.

In order to show that the Bible has its own beauty of form, Augustine gives a number of examples. In one he refers to the climax in Romans 5:3-5: 'knowing that suffering trains us to endure; and endurance brings proof that we have stood the test; and this proof is the ground of hope' (De doctr. chr. 4, 7, 11). In addition, he refers to the succession of parallel clauses (kola) in 2 Corinthians 11:16-30 (De doctr. chr. 4, 7, 12-13) and to the splendid changing figures of speech in Amos 6 (De doctr. chr. $4,7,15 \mathrm{ff})$. It is these figures of speech that appear in his own sermons over and over again, along with the alternation of question and answer (dialecticon) which he admired so much in the writings of the apostle Paul. Secondly, Augustine's use of rhyme and his plays on words are striking. In particular, the sermons given during major church festivals are, as it were, rhymed hymns, filled with plays on words. ${ }^{15}$

Hippo's bishop did not employ these literary forms simply to please his listeners. Above all he knew that these were means to instil in them important truths, and thus he demonstrates his excellence as a teacher. Today we still experience the effectiveness of his use of words when we listen to some of his phrases that are now regarded as aphorisms: 'In Novo Testamento patent, quae in Vetere latent,' in the New Testament is revealed what in the Old Testament is hidden; 'Saeculi laetitia est impunita nequitia,' the world's joy is unpunished wickedness; 'Quid est fides, nisi credere quae non vides?' what is belief if not believing what you do not see?

After pointing out the beauty of the language of the preacher's real source work, the Bible, Augustine discusses the degree of clarity in interpreting it. Here, too, he expresses a new principle:

14.On the other hand, the esteem in which Augustine was held in later times testifies to his role in setting up a new cultural ideal with his De doctr. chr.; for his influence from the 5th to the 14th century (Opelt 1974:64-73).

15. One example translated by Van der Meer (1947:375-376), a collection in the second part of Mohrmann (1974:287-456). For plays on words see Mohrmann (1936:323-349) 
One should be as clear as possible, even at the expense of (classical) language purity. Edification is only possible after comprehension. And is the purpose of all preaching not the disclosure of meaning? It is not the beauty that matters, but the truth of our words. 'What good is a golden key if it cannot open what we want it to? What objection is there to a wooden one that can, since all we want is to open what is closed?' (De doctr. chr. $4,11,26)$.

Augustine demonstrates this in his sermons: he uses a new style, accurately characterised as sermo humilis (Auerbach 1952:25-54). His belief that the minister of the Word should in his preaching follow the example of Christ, who humbled himself, can be clearly seen in M.F. Berrouard (1962:480-481). Following Christ's example one should practise humility, and the way to do this is to simplify one's language. Thus language and style are related to Bible usage and are aimed at understanding on the part of the common people. Here the church father is simple with the simple, without descending to banality. His sermons have the dedication of Scripture and the lyricism of the Christian psalms and hymns. That he could be learned with the learned is apparent in many of his letters, and especially in the stately, well-turned phrases of the City of God. He uses yet another style in the Confessions: a language of Christian culture, high in pitch, pure in tone, unforgettably beautiful.

After this homiletic advice, Augustine makes some comments on technique. Without mentioning him by name, here he follows 'a certain eloquent speaker', i.e., Cicero. Thus he brings into practice something that he likens elsewhere - in the footsteps of predecessors and contemporaries - to the Israelites' stealing the Egyptian gold and silver vessels to use them in the service of the true God (De doctr. chr. 2, 40, 60). ${ }^{16}$ Cicero distinguished three types of speaking, i.e., the simple, the flowery and the pathetic, in order to prove (probare), to delight (delectare) and to persuade (flectere) respectively, but Augustine changes them somewhat. He refers to teaching (docere), delighting and persuading. Foremost for the Church is education, the interpretation of the Word. Preaching should also serve to edify and convert. Good teaching gives delight and leads to persuasion, for to really know the truth is to act on it.

Accompanying this explaining, admonishing and persuading are three manners of presentation: composed, measured and majestic. Although basically we can say that everything the Christian speaker utters is full of grandeur (De doctr. chr. 4, 18, 35: 'omnia magna sunt quai dicimus ...') - after all, he is proclaiming eternal salvation - these differences must be maintained. For nothing tires so quickly as loftiness. The best practice is a combination of the three types. But the beginning should always be 'composed'.

Even though, in these distinctions, Augustine shows his indebtedness to classical rhetoric, he reshapes it consciously into a biblical-Christian eloquence. This is also apparent in the examples he gives of the different types of eloquence: first from the Scriptures (Paul) and then from works of Cyprian and Ambrose (De doctr. chr. 4, 20, 21-39, 50). More important than the form, however, is the content of the presentation, for the purpose of preaching is the interpretation and application of the Scriptures 'so that the truth is clear, that it pleases, that it moves' (De doctr. chr. 4, 28, 61: '... ut veritas pateat, veritas placeat, veritas moveat ...').

Before every sermon, whether it is delivered to the assembled congregation or to a smaller group, whether dictated or read aloud, the preacher is to pray 'that God might give a good word into his mouth' (De doctr. chr. 4, 30, 63: 'oret ut Deus sermonem bonum det in os eius'). Moreover, prayers should be offered 'in order that the one who praises, praises Him whose hand holds both us and our sermons' (De doctr. chr. 4, 30, 63).

16. The image became widely known through Origen and his pupils, most of whom were read by Augustine in translation. Altaner (1939:197-199) argues that, in this regard, Augustine was particularly influenced by Irenaeus. As a matter of fact, Philo of Alexandria and many others had already used the image (Allen 2008).

\section{THE IMPORTANCE OF THE MINISTRY OF THE WORD}

It is with good reason that we have made several references to prayers for God's help. More than once we are struck by this essential aspect of Augustine's preaching and of his only theoretical work on the subject. That this prayer for God's help is a central element is especially apparent when we observe how important the ministry of the Word was for Augustine (Strauss 1959; Schitzler 1968). Listening to the Word in the readings and in the singing, and then in the minister's sermon, is of so much importance because it is in fact the Holy Spirit at work here. How (quomodo) do we hear the voice of the Holy Spirit? 'The Psalm resounds, it is the voice of the Spirit; the Gospel resounds, it is the voice of the Spirit; the sermon (sermo divinus) resounds, it is the voice of the Spirit' (Tract. in Ioh. Ev. 12, 7).

It is the written Word that is preached (Dankbaar 1956:37-59; Polman 1955). ${ }^{17}$ However, Augustine states repeatedly in his sermons that the Scripture is not dead. The Bible is the Word of Salvation that is addressed to us and that creates life, comparable to a letter addressed to us (En. in Ps. 90, s 2, 1). It is not just any history that is addressed to us, but the history of salvation. According to Augustine, the entire Bible deals with Christ and bears witness to him, and that includes the Old Testament (Sermo $78,2)$. Christ is proclaimed in the Old Testament, and with him our salvation. The Gospel is the Bible's centre and apex, the document of our going astray and our redemption, sealed with divine blood (Sermo 36, 8 \& 130, 2)

The Bible is not just the Word of God that he once gave to us. It is much more directly the Word of God because he is present in it today and speaks to us. Did Christ not promise: 'See, I am with you always, to the end of time?' He ascended into heaven, but does not cease speaking to us through the Gospel: 'the mouth of Christ is the Gospel' (Sermo 85, 1: 'Os Christi evangelium est'). The Bible is not dead, it is God's living and present Word (Strauss 1959:109; Schnitzler 1968:19).

But how, then, is this Word living and present for us? God speaks through the Scriptural readings, through the Psalms, through the sermon. 'For when we speak, he is not silent; when the lector reads, he is not silent; when the Psalm sings the praises of all that, he is not silent' (En. in Ps. 93, 9). God does not cease speaking to us (En. in Ps. 130, 14: 'Ergo, fratres, non cessat Deus alloqui nos ...'). To us are addressed the instructions of the prophets, the admonitions of the apostles and the Gospel. In fact, for both readings in church, and for private Bible reading, it can be said: 'when you read, God speaks to you' (En. in Ps. 85, 7: '... quando legis, Deus tibi loquitur'). ${ }^{18}$

This holds true in relation to preaching as well. It is the ministry of the Word in which a human minister is speaking but, in actual fact, it is God who is acting. It was he who bore the ministry of the prophets, and also those of the apostles. As human speakers they were, as co-workers of God, intermediaries of God's Word to the congregation (Schnitzler 1968:85-100). And so preaching in church, if done in conformity to the Scriptures as God's Word, is still God's own speaking.

Now that we have considered the main lines of Augustine's ideas on the Word of God and the ongoing preaching of that Word, we will examine certain aspects of them in more detail. Firstly, the fact that in his sermons he frequently speaks of sermo Dei or sermo divinus. What do these expressions actually mean? Augustine often refers to the Bible as the Word of God, the

17.In the English translation of Polman's work (The Word of God according to St Augustine, London 1961) this has been taken into consideration, but not sufficiently. Augustil, Lonton After all, Scriptures and Church were not separate entities for Augustine, but together form an organic whole: the Scriptures are read, heard, preached,
understood, and applied within the community of the Church. 18.Few members of the congregation could sing, however, or acquire manuscripts of the Bible. It was possible, though, to consult them in various places 
divine Word. In doing so he generally uses the plural: sermones Dei or sermones divini, the Words of God, the divine Words. However, he also uses these words, frequently even, for the sermon delivered in church. Sermo deo or sermo divinus means the Word of God as it comes to us in the preached sermon. The preached sermon, too, is entirely 'Word of God'.

We can only understand this far-reaching view of the ministry of the Word if we are familiar with what Augustine wrote on 'the internal teacher'. Ministers and hearers have the same teacher: Christ. He gives his words to the minister to preach. In the end it is not the human minister who is speaking, but the inner teacher (magister interior) himself. That explains why Augustine emphasised prayer and regularly opened or closed his sermon with the words: God has given me the words to speak. Preaching is a gift. The working of God, of the heavenly Christ, of the Spirit, is the donare sermonem, the giving of the sermon. We find this idea over and over in the sermons that have come down to us: God's giving and granting (dare, donare), his lavishly giving (largiri), enlightening (illuminare), prompting (suggerere), inspiring (inspirare) and revealing (revelare) (Schnitzler 1968:115-116). The one who is actually at work in the sermons is God; through him they have their beginning and he carries them along.

It is clear that this also has a bearing on the hearers. The preacher can demonstrate, but he himself can give no understanding. He cannot open doors; an open door must be given to him. The inner teacher, who dwells and works in the hearts, will do this. Augustine expresses this exquisitely in his explanation of 1 John 2:27:

Take note, my beloved, of this great mystery (sacramentum): the sound of our words enters your ears, but your teacher is within you. Do not believe that a human person can teach another human. We can admonish you through the sound of our voice. But if there is not someone within you to teach you, the sound of our voice will be in vain. Look, beloved, do you want to understand it? Are you not all listening to the sermon? And how many of you will leave presently without having understood anything? As far as I am concerned, I have spoken to all of you. But those of you who are not instructed by this inner anointment, who are not internally instructed by the Holy Spirit, will leave here without knowledge. Instruction from the outside gives a kind of assistance and encouragement. But the pulpit (cathedra) of the One who teaches the hearts is in heaven. Therefore he says in the gospel: Do not let yourself be called teacher here on earth; you have one teacher, the Christ. ${ }^{19}$

(Tract. in Ep. I Ioh. 3, 13)

'We preach, but God instructs.' Augustine says this more than once (Sermo 153,1), and reminds us that Paul planted the seed and Apollos watered it, but God made it grow (Tract. in Ep. I Ioh. $10,7 ; 14,18 ; 26,7 ; 53,4 ; 97,1){ }^{20}$

We work, after all, as farmers on the land: on the outside (forinsecus). If there were no one to work from the inside (intrinsecus), no seed would become imbedded in the ground, no shoot would come forth, no twig would develop into a sturdy stem, no branches, fruit or leaves would grow. The earth trembled. But it is the heavens that drip, and they drip from the countenance of God. $^{21}$

(Sermo 152.1)

Ministering the Word is the work of the Spirit. In this belief Augustine ministered and knew its worth. To the Pelagians, who failed to do justice to God's grace, he pointed out the ministry of the Spirit who applies the Word: Christ in us, what is this if not the Holy Spirit in us? Everything is accomplished by the grace of Christ, that is, by his Spirit who dwells in us (De pecc. Mer. Et rem I, 7). The heavenly teacher gives us understanding 19.The Gospel passage is Mt 23:10.

20.In the En. in Ps. and the sermones we also see these repeated references to 1 Cor 3:6-7, obviously a central passage in Augustine's view of the ministry of the Word. De doctr. chr. 4, 16, 33 also testifies to this.

21.With quotation from and allusion to the Latin and Septuaginta Ps. 67:9 (Heb 6 8:8) of the Scriptures, which is real enlightenment. Preachers are instruments, they are not the ones who bring about salvation themselves. ${ }^{22}$

The same activity that takes place in the minister of the Word must also be present in the hearer. The inner teacher gives understanding of the message of salvation. God is at work within; he works in the heart and the thoughts (Sermo Morin 14: 'Sit vobiscum, habitet in cordibus vestris, operetur in cogitationibus vestris, florescat, quicquid veri auditis, in bonis moribus vestris'). After the church service, the preaching continues, even though the human minister is no longer present: The inner teacher dwells in men as his temple (sermo 293, 1: '... melius [!] vos docebit qui loquitur in vobis, etiam absentibus nobis quem pie cogitatis, quem corde suscepistis, cuiius templi facti estis').

Two aspects of Augustine's view of the ministry of the Word deserve to be examined in more detail. One of them we have just mentioned: The preaching of the Word itself brings about salvation. The sermon is not simply an account of affairs, a statement, but also a creating force. It is kerygma, living and dynamic preaching. It is not the minister who accomplishes this. Christ himself preaches Christ. He is it who speaks to the congregation in its state of exile and peregrination. ${ }^{23}$ God himself teaches and is at work in the heart. The preaching is unfruitful and in vain if it is not inspired and borne by God's Spirit (De civ. Dei 15, 6: '... etiamsi Deus ipse (...) sensus adloquatir humanos (...) nec interiore gratia mentem regat atque agat, nihil prodest homini omnis praedicatio veritatis'). The Word and the sermon give life to the human soul: 'From her death she rises to her life, from iniquity, foolishness and wickedness to her God, who is wisdom, justice and glory for her' (Tract. in Ioh. Ev. 19, 12). Ministering the Word cleanses and heals (En. in Ps. 42, 7); through the Gospel - for the Spirit is at work in its being preached - children of God are engendered (Contra ep. Parmeniani 2, 11, 23). ${ }^{24}$

It is surprising to note how much this emphasis on the sermon's importance for gaining salvation - primarily through Augustine's direct influence - continued to be present in later centuries. It remained to be valued almost to the end of the Middle Ages, still including the characteristic Augustinian view that the magister interior is indispensable. Though not always as explicitly, Gregory the Great, Bernard of Clairvaux, Bonaventura and the much consulted Glossa ordinara, among others, spoke about this in the same vein as Augustine (Schneyer 1962:152-170). And on the eve of the Reformation too, there were still some who made clear references to the direct significance of the sermon for salvation. However, once the Reformation had begun, most persons who remained in the Roman Catholic Church rejected this line of thinking

It was the former Augustinian monk Martin Luther who stressed the role of the ministry of the Word in attaining salvation:

Und des predigers mund und wort, das ich gehort habe, ist nicht sein, sondern des Heiligen Geists wort und predig, der da durch solch auswendig mittel inwendig den glawben gibt und also heiliget.

(Luther 1889:616)

The reformer John Calvin was also of the opinion that Christ himself teaches the congregation through the sermon; and he also emphasised the work of the magister interior, the Holy Spirit (Inst. III, 2, 37: '...nisi interiore illo magistro Spiritu per suam illuminationem aditum faciente' (Opera Selecta 4, 45). Among those opposing this reformational standpoint, particularly as it was expressed by some Calvinists, was the Roman theologian

22.Polman, Woord Gods, 168; in conjunction with ministers Augustine always used the preposition per, by means of, and never $a b$, through.

23.On the Church (and its members) as an 'alien' and being on 'peregrination', see for instance Van Oort (1991:131-142).

24.Augustine is alluding to 1 Corinthians $4: 15$. In this chapter he is defending himself against the Donatists: Unworthy ministers can indeed preach the truth; the Word remains the Word of God because God himself backs it up. 
Thomas Stapleton (c. 1590). He saw the sermon as merely a statement, as an announcement of God's will, serving only to teach facts.

We may need to reflect on this for a moment. It is surprising to observe that a Roman Catholic adherent of the so-called CounterReformation (or 'Catholic Reformation') and the present-day ultra-Reformed theologians are so much in agreement on this matter. Both parties reject the idea of direct importance of the preaching of the Word for gaining salvation. Moreover, both sides believe the sermon serves notice that something important has to occur in human life, i.e., like conversion and rebirth, but it is not the occurrence itself. However, it is fully Augustinian to notice that the Word of God which is preached both announces salvation and causes it to happen; that it both announces expiation and brings it about. In this respect both the Augustinian point of view and the Reformation point of view coincide. And above all, it appears that this view of the importance of the sermon for salvation is rooted in Scripture. ${ }^{25}$ Finally, one more aspect of how Augustine considered the ministry of the Word may be examined. For him God's word was, as spiritual food, men's daily bread. In sermons on the Lord's Prayer he tells us that the words 'Give us this day our daily bread' refer to natural bread, to the bread of the Eucharist and to the Word. 'What I explain (tracto) to you is also daily bread, just as the Scriptural readings you hear daily are daily bread. And the hymns you hear and sing are also daily bread' (Sermo 57, 7; Sermo 56, 10; 58, 5; 95, 1). 'The Word of God that is preached daily is also bread' (Sermo 59, 6). Preaching for Augustine is the breaking of bread:

When we explain the Scriptures to you we are, as it were, breaking the loaves. What I hand out is not mine. What you eat, I eat. What you live on, I live on. We have together our storeroom in heaven. For that is where the Word (verbum) of God comes from.

(Sermo 95, 1; Sermo 58, 5; Sermo 130,1)

Likewise he compares the Gospel to good wine (Tract. in Ioh. Ev. $9,2)$, and he sees the heavenly manna as the Word of God (En. in Ps. 77, 17).

From all this it is clear that Augustine ascribed great value to the Word and its ministry. He compared the ministry of the Word to the celebration of Holy Communion, and considered the two of equal value. It is striking that he used the same terminology for the preaching of the Word as for the celebration of Holy Communion. He spoke of a 'banquet of the Scriptures' that is being prepared at 'the table of the Lord' (Sermo 90, 9: convivium sanctuarum scripturarum; mensa Domini; Tract. in Ioh. Ev. 9, 9: mensa Domini), of 'food' (En. in Ps. 88, s. 1, 29; Tract. in Ep. I Ioh. 6, 14), of spiritual 'bread' (sermo 56, 10). 'We, however, who have gathered together, let us exult at the meal of God; may his Word (sermo) be our joy. For He has invited us to his gospel and He is our food' (Tract. in Ioh. Ev. 7, 2). What is referred to here is the reading from the Gospel along with its interpretation. For the sermon itself is the sermon brought by God (Christ, the Spirit); and Christ, as being God's gift of grace, is the spiritual food.

Just as at Holy Communion, Christ is present in the Word and in the ministry of the Word. Augustine used the words table (mensa), banquet (convivium) or bread (panis) in referring to

\footnotetext{
25.An examination of this lies outside the framework of the present study. I only refe to the New Testament, in particular to what Paul says in 1 Corinthians 1:18ff., 2 Corinthians 5:17ff. and Romans 10:9ff. For 'kèryssein' in the New Testament see Friedrich in TWNT III, $701 \mathrm{ff}$; among other things he notes: '...das verkündete Wort ist ein götliches Wort und als solches eine wirkende Macht, die auch schafft Wort und als solches eine wirkende Macht, die auch schaft was verkindet wird. Darum ist Predigen nicht eine Tatsach Die Verkung, sonder ein Geschehen. Es geschieht was ausgerufen wird. (...) Die Verkündigung der Heilsbotschaft wirkt Scheidung und Trennung. Dem einen wird sie zur Rettung, dem andern zum Gericht' (710). It may be noted that this central aspect is lacking in most 'liberal' views on the value of the sermon as well. From its earliest times onwards, the sermon - both in the Jewish synagogue and, subsequently, in the Christian Church - is much more than telling some interesting stories or considering religious issues. From the previous paragraphs it may not be derived that modern Roman Catholic views of (the value of) the sermon are still those of Stapleton cum suis. The salvational value of the sermon is stressed by for instance, famous Romen Catholic the Roman Cathic theologians like Karl fine overview and systematic reflection has been provided by Leo Scheffczyk (1966). Beutel (2003:1590-1591) and Fuchs (2003:1592-1594) give a brief overview of modern Roman Catholic thinking.
}

both of them. The ministry of Word and sacrament are needed together because Christ's flock cannot live without this ministry (Ep. 228, 2). They are of equal value and very closely connected with each other. One ministry is impossible without the other.

\section{CONCLUSION}

We have examined some essential aspects of Augustine as a minister and a preacher of the Word. If the reader's reaction is similar to the author's, (s)he, too, will be able to speak of a frequently interesting voyage of discovery.

One is struck by Augustine's influence on later generations. They have borrowed from his sermons extensively, used them as their examples and, in this way, preserved the leading Augustinian ideas contained in them. The position of the Psalms in the worship service is also noteworthy. They were read as a lesson from Scripture and sung as a response to the Scripture reading. In this practice one detects the influence of the original worship service of the synagogue. The singing of Psalms that is still practised at times, in combination with the Scriptural readings, can be traced back to the liturgy of the synagogue. Is this ancient practice not worthy of serious (re)consideration?

The central position that was given to the Psalms by Augustine, his contemporaries, predecessors (Fischer 1949), and many after him seems to be based on this custom. The Psalms were christologically interpreted and applied, and in a special sense but not exclusively - considered to be God's own songs.

We indicated why various elements of the worship service in Augustine's day argue in favour of a Jewish Christian origin of the African Church (Van Oort 1991:365-371) ${ }^{26}$ At the same time, important roots characteristic of worldwide Christianity are to be found here. Augustine's method of Bible interpretation was probably influenced by the synagogue, and it was this Bible interpretation that had such a great influence over centuries. Sometimes, however, its multiplicity of allegorical explanations seems strange to us. But would it not be possible, even here, to detect some vestiges of synagogue practice (Billebeck 1928:388399)? The allegorical interpretation was used not only in the mixed society of Alexandrian Jews, but also among Palestinian Jews (number symbolism is also used by both). And does this ancient practice of allegorical and, not least, 'typological' explanation of Scripture (Goppelt 1939; Alsup 1992:682-685; Byassee 2007:9-53) not have more rights than some are willing to see?

Moreover, the emphasis on praying by the minister and the congregation may have originated here; or there is at least a remarkable analogy. In the synagogue, too, there were prayers for 'the hearing, learning, teaching and keeping' of the Torah (Hedegård 1951:46-51). It is striking that the prayer asking God for enlightenment is an essential element of Augustine's ministry of the Word. The Paraclete is considered to be the real exegete. With this presentation of the Spirit he can refer to the sermon as sermo Dei or sermo divinus: God's Word or divine address. The magister interior is at work both in the preacher and in the listening congregation. This explains Augustine's emphasis on the pivotal importance of the ministry of the Word in humanity's salvation. Finally, it is characteristic of Augustine to use the same terminology for the sermon as for Holy Communion (the Eucharist): the two are of equal value, and essentially very closely related.

Does the expression 'Augustinus totus noster' used by Luther, Calvin and other reformers also hold for present-day Protestants? Is the African church father 'completely ours' indeed? From the foregoing it would appear that in their rediscovery of the value of the sermon, Luther and Calvin could find Augustine on their side. That is certainly true for the central aspects as we have described them. Moreover, that is evidently the case for Augustine's work De doctrina christiana.

26. My most recent overview in the lexicon article 'ludaei', Augustinus-Lexikon, Basel 2008 (in print). 
This manual for exegesis and homiletics played a major role in Zwingli's Der Hirt. This work was translated and published by Caspar Hedio as The Shepherd (Old 1975:187), and it appears to have exerted a strong influence on Bucer and Calvin too. Even the latter's argumentation in favour of biblical hymns, with his preference for the Psalms, was for the most part inspired by Augustine's sermons. ${ }^{27}$

For many present-day Reformed Christians there is, however, one central fact in Augustine's preaching that still merits special attention. The church father clearly saw sermon and Eucharist (Holy Communion) as a duality. They deal with the same Word; both of them minister the Word. This connection has existed from the very start of the first Christian congregations onwards: The first Jerusalem Christians 'devoted themselves to the apostles' teaching, to the sharing of the common life, to the breaking of the bread, and to the prayers' (Ac 2:42) (Cullmann 1950:29-34; Jackson \& Lake 1933:27-28). Thus the order and sequence in the early Christian church were maintained: The sermon had a fixed place between the Scriptural readings and the long prayer offered at the beginning of the celebration of Holy Communion. The decline of the sermon and the communion celebration started when they were separated. This was particularly noticeable in the Middle Ages. At the time, the sermon (when it still took place) was often delivered apart from the rest of the worship service. Moreover, the separate celebration of Holy Communion declined into a ritual which most people partook in only once a year.

What exactly was the far-reaching reforming work of Luther and Calvin, both of whom were so much influenced by Augustine? They argued for the re-instatement in the worship service of the earlier duality: The ministering of the Word in the sermon and the regular celebration of Holy Communion. Luther is known to have urged frequent celebrations, and even mentioned the idea of holding them daily. What many people do not realise is that Calvin had a similar view. He, too, argued in favour of the congregation's celebrating the Lord's Supper at least once a week. Even though his idea could not be put into practice because of unwillingness on the part of the city council and the people of Geneva, Calvin still adhered to this view as a matter of principle. This is especially clear in a passage of the Institutes which, in the course of its subsequent editions, has remained notably unchanged. In it Calvin pointed not only to Scriptural evidence but also to Augustine as the basis for his view (Inst. IV , 17, 44-46).

Along with the other features of Augustine as minister of the Word, this view of the African church father may deserve serious consideration in our day as well. Even today Augustine and his sermons have their significance.

\section{REFERENCES}

Allen, J.S., 2008, The Despoliation of Egypt in Pre-Rabbinic, Rabbinic and Patristic Traditions, Brill, Leiden.

Alsup, J.E., 1992, 'Typology', The Anchor Bible Dictionary vol. VI, pp. 682-685, Doubleday, New York.

Altaner, B., 1939, 'Augustinus und Irenäus,' reprinted in Kleine Patristische Schriften (1967), pp. 194-203, Akademie Verlag, Berlin.

Auerbach, E., 1952, 'Sermo humilis', reprinted in Literatursprache und Publikum in der lateinischen Spätantike und im Mittelalter (1958), Francke Verlag, Bern.

Augustinus, St., 1995, De Doctrina Christiana, transl. R.H.P. Green (ed.), Clarendon Press, Oxford.

Augustinus, St., 1999, 'Wat betekent de bijbel? Christelijke scholing in tekstbegrip en presentatie', De doctrina christiana, ingeleid, vertaald en toegelicht door Jan den Boeft en Ineke Sluiter, Ambo/Kritiek, Leuven

Augustinus, St., 1948, Preken voor het volk handelende over de Heilige Schrift en het eigen van den tijd, Spectrum, Utrecht.

27.Calvin pointed also to Chrystosom and to the decisions of Councils. It is noteworthy that the church reformer referred - selectively - to early Church tradition, and not to the Bible itself.
Backus, I., 1997, The Reception of the Church Fathers in the West, Brill, Leiden.

Bastiaensen, A.A.R., 1975, Vita di Cipriano, Vita di Ambrogio, Vita di Agostin, Fondazione Lorenzo Valla/Arnoldo Mondadori Editore, Verona.

Berrouard, M.F., 1962, 'Saint Augustin et le ministère de la prédication', in Recherches Augustiniennes II, Études Augustiniennes, Paris.

Beutel, A., 2003, Die Religion in Geschichte und Gegenwart VI 1590-1591, Mohr, Tübingen.

Billerbeck, P., 1928, Kommentar zum Neuen Testament aus Talmud und Midrasch, C.H. Beck, München.

Brown, P., 1967, Augustine of Hippo: A biography, Faber \& Faber, London.

Byassee, J., 2007, Praise Seeking Understanding. Reading the Psalms with Augustine, Eerdmans, Grand Rapids.

Cullmann, O., 1950, Urchristentum und Gottesdienst. Zwingli Verlag, Zürich.

Daniélou, J., 1977, The Origins of Latin Christianity, Darton, Longman \& Todd, London.

Dankbaar, W.F., 1956, 'Schriftgezag en Kerkgezag bij Augustinus', Nederlands Theologisch Tijdschrift 11, 37-59.

De Jong, O.J., De Greef, W. \& Van Campen, M., 1991, Reformatie in meervoud. Congresbundel 1990, De Groot Goudriaan, Kampen.

Dekkers, E. \& Gaar, A., 1953, Clavis Patrum Latinorum, Brepols, Turnhout.

Den Boeft, J. \& Kessels, A.H.M., 1982, Actus. Studies in Honour of H.L. Nelson, Faculteit der Letteren, Utrecht.

Den Boeft, J. \& Poll-van de Lisdonk, M.L. (eds.), 1991, The Impact of Scripture in Early Christianity, Brill, Leiden.

Dolbeau, F., 2005, 'Augustin et la prédication en Afrique', in Recherches sur divers sermons authentiques, apocryphes ou anonyms, Études Augustiniennes, Paris.

Elm, E., 2003, Die Macht der Weisheit. Das Bild des Bischofs in der Vita Augustini des Possidius und anderen spätantiken und frühmittelalterlichen Bischofsviten, Brill, Leiden.

Fischer, B., 1949, Die Psalmenfrömmigkeit der Märtyrkirche, Universitätsverlag, Freibourg.

Frend, W.H.C., 1961, 'The Seniores Laici and the Origins of the Church in North Africa', Journal of Theological Studies 12, 280-284.

Fuchs, O., 2003, 'Predigt, III', in RGG VI 1592-1594, Mohr, Tübingen.

Goppelt, L., 1939, Typos. Die typologische Deutung des Alten Testaments im Neuen, Bertelsmann Verlag, Gütersloh.

Grane, L., Schindler, A. \& Wriedt, M., (eds.), 1993, Auctoritas Patrum. Contributions on the Reception of the Church Fathers in the 15th and 16th century, Verlag Philipp von Zabern, Mainz.

Hagendahl, H., 1974, 'Die Bedeutung der Stenographie für die spätlateinische christliche Literatur', Jahrbuch für Antike und Christentum 14, 24-38.

Hamman, A.G., 1986, La vie quotidienne en Afrique du Nord au temps de Saint Augustin, Hachette, Paris.

Hedegård, D., 1951, Seder R. Amran Gaon, I, Lindstedts Universitets Bokhandel, Lund.

Jackson, F.J.F. \& Lake, K. (eds.), 1933, 'The Beginnings of Christianity, Part I', in The Acts of the Apostles, vol. IV, transl. K. Lake \& H.J. Cadbury, Macmillan and Co, London.

Kany, R., 2007, Augustins Trinitätsdenken, Mohr, Tübingen.

Kotzé, A., 2004, Augustine's Confessions: Communicative Purpose and Audience, Brill, Leiden.

Krause, G., 1968, 'Anredeformen der christlichen Predigt', in Wort und Welt. Festgabe für Professor D.E. Hertzsch, Evangelische Verlagsanstalt, Berlin.

La Bonnardière, A.M., 1965, Recherches de chronologie augustinienne, Études Augustiniennes, Paris.

Lange van Ravenswaay, J.M.J., 1990, Augustinus totus noster. Das Augustinverständnis bei Johannes Calvin, VandenHoeck \& Ruprecht, Göttingen.

Luther, M., 1889, Weimarer Ausgabe, Band 18, Hermann Böhlaus Nachfolger, Weimer. 
Madec, G., 1998 (ed.), 'Augustin prédicateur (395-411)', in Actes du Colloque International de Chantilly, Études Augustiniennes, Paris.

Mandouze, A., 1968, Saint Augustin. L'aventure de la raison et de la grace, Études Augustiniennes, Paris.

Marrou, H.I., 1939, Augustin et la fin la culture antique, De Boccard, Paris.

Marrou, H.I., 1955, St. Augustin et l'augustinisme, Éditions du Seuil, Paris.

Millemann, H., 1933, 'Caesarius von Arles und die frühmittelalterliche Missionspredigt', Zeitschrift für die Missionswissenschaft 23, 23-24.

Mohrmann, C., 1974, Augustinus. Preken voor het volk, Het Spectrum, Utrecht en Brussel.

Mohrmann, C., 1936, Das Wortspiel in den Augustinischen Sermones, Ed. Di Storia e Letteratura, Rome.

Niebergall, A., 1955, 'Die Geschichte des christlichen Predigt', Leiturgia. Handbuch des evangelischen Gottesdiens II, 25.

Old, H.O., 1975, The Patristic roots of Reformed worship, Theologischer Verlag, Zürich.

Olivar, A., 1966, 'La duratión de la predicación antigua', Liturgica 3, 143-184.

Opelt, I., 1974, 'Materialien zur Nachwirkung von Augustins Schrift De Doctrina christiana', in Jahrbuch für Antike und Christentum, Aschendorff Verlag, Münster.

Perler, O., 1969, Les voyages de saint Augustin, Études Augustiniennes, Paris.

Polman, P., 1932, L'Élément historique dans la Controverse religieuse du XVIe Siècle, Imprimerie J. Duculot, Gembloux.

Polman, A.D.R., 1955, Het Woord Gods bij Augustinus, Kok, Kampen.

Pontet, M., 1945, L'exégèse de S. Augustin prédicateur, Aubier, Paris.

Poque, S., 1966, Augustin d'Hippone, Sermons pour la Pâque, Les Éditions du Cerf, Paris.

Quispel, G., 1982, 'African Christianity before Minucius Felix and Tertullian,' in J. den Boeft \& A.H.M. Kessels (eds.), Actus. Studies in Honour of H.L. Nelson, pp. 257-335, Faculteit der Letteren, Utrecht.

Rebillard, E., 1999, 'Sermones', in Augustine through the ages: An encyclopedia, Cambridge, Grand Rapids.

Roetzer, W., 1930, Des heiligen Augustinus Schriften als liturgiegeschichtliche Quelle, Hüber, München.

Scheffczyk, L., 1966, Von der Heilsmacht des Wortes. Grundzüge einer Theologie des Wortes, Hüber, München.

Schneyer, J.B., 1962, 'Die Heilsbedeutung der Predigt in der Auffassung katholischer Prediger', Zeitschrift für katholische Theologie 84, 152-170.

Schnitzler, F., 1968, Zur Theologie der Verkündigung in den Predigten des hl. Augustinus. Ein Betrag zur Theologie des Wortes, Herder, Freiburg.
Simon, M., 1962, Recherches d'Histoire Judéo-Chrétienne, Mouton \& Co, Paris

Sizoo, A., 1939, Eloquentia divina, Meinema, Delft.

Sluiter, I., 1999, 'Communication, Eloquence and Entertainment in Augustine's De doctrina Christiana,' in J. den Boeft \& M.L. Poll-van de Lisdonk (eds.), The Impact of Scripture in Early Christianity, pp. 245-267, Brill, Leiden.

Sluiter, I., 2005, 'Lezen als levensreis: Een metafoorcomplex bij Augustinus,' in P.Van Geest \& J.Van Oort (eds.), Augustiniana Neerlandica. Aspecten van Augustinus' spiritualiteit en haar doorwerking, pp. 103-111, Peeters, Leuven.

Smits, L., 1956, Saint Augustin dans l'oeuvre de Jean Calvin, vol. I., Van Gorcum, Assen.

Stakemeier, E., 1937, Der Kampf um Augustin. Augustinus und die Augustiner auf dem Tridentinum, Verlag der BonifaciusDruckerei, Paderborn.

Strauss, G., 1959, Schriftgebrauch, Schriftauslegung und Schrifbeweis bei Augustin, Mohr, Tübingen.

Van der Meer, F., 1947, Augustinus de zielzorger. Een studie over de praktijk van een kerkvader, Het Spectrum, Utrecht.

Van Geest, P. \& Van Oort, J. (eds.), 2005, Augustiniana Neerlandica. Aspecten van Augustinus' spiritualiteit en haar doorwerking, Peeters, Leuven.

Van Oort, J., Graafland, C., De Groot, A. \& De Jong, O.J., (reds.), 1989, De onbekende Voetius. Voordrachten wetenschappelijk symposium Utrecht 3 maart 1989, Kok, Kampen.

Van Oort, J., 1991a, Jerusalem and Babylon. A Study into Augustine's City of God and His Doctrine of the Two Cities, Brill, Leiden.

Van Oort, J., 1991b, 'Was de Reformatie een Augustiniaans Réveil?' in De Jong, O.J., De Greef, W. \& Van Campen, M. (eds.), Reformatie in meervoud. Congresbundel 1990, De Groot Goudriaan, Kampen.

Van Oort, J., 1992, 'Calvijn en Augustinus', in Nederlands Archief voor Kerkgeschiedenis/Dutch Review of Church History 72, 92103.

Van Oort, J., 1997a, 'John Calvin and the Church Fathers,' in I. Backus, Reception of the Church Fathers in the West, pp. 661700, Brill, Leiden.

Van Oort, J., 1997b, 'Calvinus patristicus: Calvijns kennis, gebruik en misbruik van de patres,' in J. Van Oort (ed.), De Kerkvaders in Reformatie en Nadere Redormatie, pp. 67-81, Boekencentrum, Zoetermeer.

Verbraken, P.P., 1976, Études critiques sur les sermons authentiques de saint Augustin, Instrumenta patristica, XII, no. 350, Abatia S. Petri-Mar tinus Nijhoff, Steenbrugge-Den Haag.

Zunz, L., [1892] 1996, Die gottesdienstlichen Vorträge der Juden historisch entwickelt, Olms, Hildesheim.

Zwinggi, A., 1970, 'Der Wortgottesdienst bei Augustinus', Liturgisches Jahrbuch 20, 93-94.

Zwinggi, A., 1970a, 'Die fortlaufende Schriftlesung im Gottesdienst bei Augustinus', Archiv für Liturgiewissenschaft $12,85-129$. 